\title{
Musul Atabeglerinin Meşhur Devlet Adamı: Cemâleddin el-İsfahânî (ö. 559/1164)*
}

\section{A Famous Statesman of the Atabegs of Al-Mawṣıl: Djāmal Al-Dīn Al-Iṣfahānī (D. 559/1164)}

\author{
Pinar KAYA TAN ${ }^{1}$
}

* Bu çalıșma 28-29 Mayıs 2021 tarihleri arasında Nusaybin'de düzenlenen Uluslararası Nusaybin Sempozyumu'nda sunulan bildiri metninin yeni verilerle genişletilmesi suretiyle hazırlanmıştır.

'Kırklareli Üniversitesi Fen-Edebiyat Fakültesi Tarih Bölümü, Ortaçağ Tarihi Anabilim Dalı, Kırklareli, Türkiye

ORCID: P.K.T. 0000-0002-7025-399X

Sorumlu yazar/Corresponding author: Pınar KAYA TAN (Dr. Öğr. Üyesi),

Kırklareli Üniversitesi Fen-Edebiyat Fakültesi, Tarih Bölümü, Ortaçağ Tarihi Anabilim Dalı,

Kırklareli, Türkiye

E-posta: pinarkaya@klu.edu.tr

Başvuru/Submitted: 22.06 .2021 Revizyon Talebi/Revision Requested: 03.07.2021

Son Revizyon/Last Revision Received: 29.07.2021

Kabul/Accepted: 03.08.202

Atıf/Citation: Kaya Tan, Pinar. "Musul Atabeglerinin Meşhur Devlet Adaml: Cemâleddin El-İsfahânî (Ö. 559/1164)". Şarkiyat Mecmuası - Journal of Oriental Studies 39 (2021) 203-222.

https://doi.org/10.26650/jos.955728 öz

Atabeg İmâdeddin Zengî́nin (521-541/1127-1146) Musul'a vâli olarak tâyin edilmesinden îtibâren I. Seyfeddin Gazi (541-544/1146-1149) ve Mevdûd b. İmâdeddin Zengî (544-565/1149-1170) dönemlerinde de Musul Atabeglerine (521-631/1127-1233) hizmet eden, vezîrlik makamına yükselerek devleti idâre eden devrin etkin ve mühim şahsiyetlerinden biri Cemâleddin el-İsfahânî'dir. Dirâyetli, başarılı üstün yöneticilik vasıflarıyla kuruluş sürecinden îtibâren Musul Atabegliği'ne önemli hizmetlerde bulunmuş, kendisine İmâdeddin Zengî tarafından Nusaybin ve ardından da Rahbe'nin idâresi verilmiştir. Atabeg İmâdeddin Zengî́nin vefatından sonra yaşanan iç karışıklıkların büyümesini önlemeyi başarmış; sonraki dönemlerde ise iç meselelerle olduğu kadar çevre hükümdarlarla yaşanan siyasî hadiselerde de arabuluculuk yaparak bölgede sükûneti sağlamaya gayret gösteren bir vezîr olmuştur. Bağdat'tan İsfahân'a kadar muhtelif memleketlerdeki hükümdar, melik, devlet görevlileri, âlim ve ediplerin saygısını kazanmış, teveccühlerine mazhar olmuştur. Daha çocukluğundan başlayarak usûl, erkân terbiyesi alan ve eğitimine büyük ihtimam gösterilen Cemâleddin el-İsfahânî, bilhassa güzel ahlâkı ve yapmış olduğu hayırseverlikleri ile "el-Cevâd" (cömert) namıyla tanınır olmuştur. Musul, Sincar başta olmak üzere Nusaybin'den Haremeyn'e kadar pek çok şehirde tesis ettiği hayır kurumları, yapmış olduğu bağışları, iyilikleriyle halkın sevgisini ve duâsını eksik etmediği yöneticilerden biri olarak görev yapmıştır. Bu araştırmada mezkûr devlet adamının yaşadığı devirdeki siyasî rolü gözler önüne serilecek, ayrıca çeşitli merkezlerdeki yardım faâliyetleri, inşâ ettirmiş olduğu hanlar, ribâtlar, hastaneler gibi içtimaî kurumlar Ortaçağ tarihî kaynaklarının verdiği bilgiler ışığında ele alınacaktır.

Anahtar kelimeler: Cemâleddin el-i̇sfahânî, Musul Atabegleri, İmâdeddin Zengî, I. Seyfeddin Gazi, Musul

\section{ABSTRACT}

Djāmal al-Dīn al-Ișfahānī, served the Atabegs of al-Mawșil during the reigns of both Sayf al-Dīn Ghāzī I (541_544/1146_1149) and Mawdūd b. 'Imad al-Dīn Zangī (544_565/1149_1170). After the appointment of Atabeg 'Imad al-Dīn Zangī (521_541/1127_1146) as the governor of al-Mawșil, Djāmal al-Dīn alIṣfahāni rose to the position of vizier. He is among the prominent and important personalities of the era. Relying on his astute, strong, superior administrative 
skills, Djāmal al-Dīn al-Ișfahānī offered his services to the Atabeg of al-Mawșil from the start and was granted the rule of Nașībīn and later Raḥba by 'Imad al-Dīn Zangī. Djāmal al-Dīn al-Iṣfahānī, managed to prevent internal struggles after the death of Atabeg 'Imad al-Dīn Zangī. As a vizier he struggled to ensure peace in the region by acting as a negotiator in political incidents with neighboring rulers as well as by containing internal unrest. Djāmal al-Dīn al-Ișfahānī earned the respect of many rulers, maliks, statesmen, intellectuals, and scholars of states from Baghdād to Ișfahān. Trained in manners and customs from a young age and being thoroughly educated, Djāmal al-Dīn al-lșfahānī came to be known as"al-Djawād"(the noble), renowned especially for his morality and charity. He was a leader who was bestowed with the affection and prayers of the public with the charities he founded in many cities from al-Mawșil to Sindjār and Nașībīn to al-Haramayn, as well as hefty donations and benevolence. This study will reveal the political role of this venerable statesman in his era and discuss his donations and the social institutions he constructed, such as caravanserais, ribats and hospitals, in various centers in light of the historic sources of the Middle Ages.

Keywords: Djāmal al-Dīn al-Ișfahānī, Atabegs of al-Mawșil, 'Imad al-Dīn Zangī, Sayf al-Dīn Ghāzī l, al-Mawșil

\section{EXTENDED ABSTRACT}

Djāmal al-Dīn Muḥammad al-Ișfahānī was the most prominent statesman who served the Atabegs of al-Mawșil (Zangids) during the reigns of Atabeg 'Imad al-Dīn Zangī, Sayf alDīn Ghāzī I, and Mawdūd b. 'Imad al-Dīn Zangī. He attempted to ensure the survival of the Atabegs of al-Mawșil and is regarded more for his charitable acts than his political success. This study determines the political actions and charitable works of the most famous vizier of the Atabegs of al-Mawșil.

Raised in a family that served at various levels in the service of the Seljuq șultans, Ișfahānī quickly drew attention with his state training. He managed to enter the court entourage of Atabeg 'Imad al-Dīn Zangī and became one of the favorite amīrs of the Atabeg thanks to his administrative skills. He was appointed the mayor of Nașīiñ and Raḥba and then was responsible for the dīwan of Zangī. When Atabeg was martyred, Djāmal al-Dīn Muhammad al-Ișfahānī made outstanding efforts to ensure that his son, Sayf al-Dīn Ghāzī I ruled over al-Mawșil. However, Sayf al-Dīn Ghāzī I did not last long as the Atabeg of al-Mawșil, and when he suddenly fell ill, vizier Djāmal al-Dīn had also been influential in replacing him with his brother Mawdūd b. 'Imad al-Dīn Zangī. Vizier Djāmal al-Dīn Muhammad al-Ișfahānī has also played a role in establishing peace in international relations with his political influence and authority. He did not hesitate to send his envoys to the Georgian King to receive the prisoners after the Muslim forces gathered in eastern Anatolia had been heavily defeated in their battles with Georgians. He made an effort to establish good relations with neighboring states and the Abbāsid Caliphate.

The most important aspect of Djāmal al-Dīn Ișfahānī has been his philanthropy, generous grants to those in need, charity, and benevolence even in geographic locations far from alMawșil. He even donated the clothing he wore during a famine. People from all walks of life whom, he helped attended the funeral of Djāmal al-Dīn Muhammad al-Ișfahānī, protector of the weak, orphans, and homeless. He had always shown respect to the scientists, devotees, sūfis 
and poets of the era, who wrote eulogies for the vizier on his death. He built ribats in cities such as al-Mawșil, Nașībīn and Sindjār and established a school for orphans and homeless children. He built bridges over the Tigris and founded a hospital in Nașībīn, covering the costs of medicine and doctors. Providing great charity to the residents of Makkah and Medina, the vizier sent aid to meet the needs of the poor in these cities annually, established water sources for Arafah, repaired mosques, and ended raids by enclosing Medina within city walls.

The rapid rise of Djāmal al-Dīn al-Ișfahānī under Atabegs and his becoming the vizier had caused discontent among other statesmen. Using his means abundantly for the benefit of the people must have caused a reaction because the vizier who had played a significant role in the history of the Atabegs was dismissed and arrested through the efforts of his opposition. He died in 559 (1164) in the castle where he was held prisoner. His body was buried in alMawșil, but it was first taken to al-Haramayn with a convoy according to his will, and funeral prayers and commemoration ceremonies were held at every location on the road for the vizier. 


\section{Giriş}

Musul Atabeglerinin (Zengîler) önemli devlet adamlarından Cemâleddin Muhammed elİsfahânî'nin Nusaybin ve Rahbe'nin' idâreciliğiyle başlayan ve devrin kıymetli vezirlerinden olmasını sağlayan siyasî faâliyetleri, gerçekleştirmiş olduğu hayır ve hasenâtı ve kaynakların imkân verdiği ölçüde biyografisinin tespiti bu çalışmanın yazılış amacını oluşturmaktadır. Cemâleddin Muhammed el-İsfahânî'nin doğum tarihi ve etnik menşei hakkında kaynaklarda mâlûmata rastlamak mümkün olmamıştır. Bununla birlikte adındaki İsfahânî nisbesinden dolayı onun İranlı olduğu düşünülebilir. ${ }^{2}$ Nitekim Selçuklular döneminde iyi tahsil görmüş kabiliyet sâhibi İranlılar devletin pek çok kademesinde görev yapmışlardı. Nitekim Vezir İsfahânî’nin âilesi de Büyük Selçukluların maiyetinde yer almıştı. Cemâleddin Muhammed el-İsfahânî’nin büyükbabası Ebû Mansûr Cevâd el-İsfahânî, pars yetiştiricisi (fehhâd) ${ }^{3}$ olarak Büyük Selçuklu Sultanı Melikşah'ın (465-485/1072-1092) hizmetinde bulunmuş; ${ }^{4}$ babası Ali ise iyi bir eğitim almış, yüksek makamlara yükselmiş, ciddî meselelerde görüşlerine değer verilen devlet adamlarından biri olarak Vezir Şemsülmülk Osman b. Nizâmülmülk'ün (ö. 517/1123) hâcibi olarak görev yapmıştır. ${ }^{5}$ Cemâleddin Muhammed el-İsfahânî de âilesinin yanında oldukça iyi bir eğitim almış ve ihtimamla yetiştirilmişti. Meşhur edip ve tarihçi İmâdeddin el-İ́sfâhânî’nin (ö. 597/1201) amcası olup genç yaşına rağmen dönemin önde gelen kâtipleri arasında yer almış olan Azîzüddin Ebû Nasr Ahmed b. Hâmid'in dayılarından birinin oğlu ile Cemâleddin el-İsfahânî’nin kız kardeşi arasında evlilik bağı tesis edilmişti. Bu münâsebetle Azîzüddin Ebû Nasr Ahmed b. Hâmid, Cemâleddin'i himâyesine almış, onun ahlâk ve terbiyesiyle yakından ilgilenerek ilmî gelişiminde ve devlet mertebesinde yükselmesine vesile olmuştur. ${ }^{6}$ Yaşanan olumlu gelişmelerin ve aldığı eğitimlerin etkisiyle üstün vasıflarıyla da dikkat çeken Cemâleddin çok geçmeden Irak Selçuklu Sultanı Mahmûd b. Muhammed Tapar'ın (512-525/1118-1131) hizmetine girmiş; Dîvânü'l-arz'da görev yaparak sâhip olduğu hasletler ile dikkat çekmiştir.'

Irak Selçuklu Sultanı Mahmûd b. Muhammed Tapar, Halep Vâlisi Kasîmüddevle Aksungur'un (ö. 487/1094) oğlu olup ve İslâm dünyasının önemli kumandanlarının himâyesinde yetiştirilen İmâdeddin Zengî'yi Musul vâlisi ve ayrıca oğlu Melik Alparslan'a da atabeg olarak tâyin etmişti. İmâdeddin Zengî'nin Musul'a yerleşmesiyle beraber Musul Atabegliği’nin (Zengîler)

1 Fırat Nehri kıyısındaki şehir için bkz. G. Le Strange, Doğu Hilafetinin Memleketleri, çev. Adnan Eskikurt ve Cengiz Tomar (İstanbul: Yeditepe Yayınevi, 2015), 148; E. Honigmann, "Rahbe”, İA, IX, (İstanbul: MEB, 1964), 601-604.

2 Halil İbrahim Gök, "XII. Yüzyılda Musul'da Yaşamış Seçkin Bir Sima: "Vezir Cemâleddin Muhammed elİsfahân̂̂”, Bilim Yolu, Kırıkkale Üniversitesi Sosyal Bilimler Enstitüsü Dergisi 3 (2003), 511-512.

3 Avlanmak için parslara öğreticilik yapanlara fehhâd denilmektedir. Bkz. M. Alî Ekber Dihhudâ, Lug்atnâme, çev. M. Muîn ve Seyyid Ca fer Şehîdî (Tahran: Tahran Üniversitesi, 1998), XI: 17243.

4 Bündârî, Zübdetü'n-Nusra ve nuhbetü'l- 'usra, çev. Kıvameddin Burslan, Irak ve Horasan Selçukluları Tarihi (İstanbul: Maarif Matbaası, 1943), 191; İbn Hallikân, Vefeyâtü'l-a'yân, nşr. İhsan Abbas (Beyrut: Dâru Sâdır, 1397/1977), V: 143.

5 Bündârî, Zübdetü'n-Nusra, 191.

6 Bündârî, Zübdetü'n-Nusra, 192; Halil İbrahim Gök, Musul Atabeyliği Zengiler (Musul Kolu 1146-1233), (Ankara: TTK, 2013), 119.

7 Bündârî, Zübdetü'n-Nusra, 192; İbn Hallikân, Vefeyâtü'l-a‘yân, V: 143. 
temelleri atılmış oldu. İmâdeddin Zengî, Musul'da işleri yoluna koyduktan sonra kısa bir süre sonra bir kısmı Artuklu hâkimiyetindeki Cizre, Nusaybin, Sincâr, Habur, Harran ve Haleb'i de ele geçirdi. ${ }^{8}$

\section{a) Siyasî Faâliyetleri}

İmâdeddin Zengî'nin Musul ve çevresinde hâkimiyeti ele geçirmesiyle birlikte Cemâleddin Muhammed el-İsfahânî de İmâdeddin Zengî’nin maiyetine dâhil olmuştur. 'I İmâdeddin Zengî, 517 (1123-1124) yılında ölen emîrlerden Gündoğdu'nun ${ }^{10}$ hanımı ile Sultan Mahmûd'un da teşvikiyle evlenmiş ${ }^{11}$ ve bu hatunun önceki evliliğinden olan ve Hasbek adlı oğluna Azîzüddin Ebû Nasr Ahmed b. Hâmid'in tavsiyeleriyle Cemâleddin el-İsfahânî'yi vezir olarak görevlendirmiştir. ${ }^{12}$ İsfahânî, sözü, sohbeti güler yüzü, dürüstlüğü ile İmâdeddin Zengî’nin teveccühünü kazanmış; kısa zamanda onun yakın arkadaşları arasında yerini almıştı. ${ }^{13}$ Musul Atabegi, Nusaybin'e vâli olarak tâyin ettiği Cemâleddin el-İsfahânî’ye bu makamında görevini lâyıkıyla yerine getirmesi sebebiyle Rahbe'nin idâresini de vererek yetkilerini artırmıştır. ${ }^{14}$ Çok geçmeden İmâdeddin Zengî, Dîvân-1 İşrâf' $1 n^{15}$ başına Cemâleddin Muhammed el-İsfahânî’yi getirerek sorumluluğunu daha da artırmıştır. ${ }^{16}$ Cemâleddin Muhammed el-İsfahânî’nin bu kadar kısa sürede devlet idâreciliğinde yükselmesinde çocukluğundan îtibâren aldığı eğitimin, terbiyenin, âilesi ve yakınları tarafından özveriyle yetiştirilmesinin etkisi olduğu kadar İmâdeddin Zengî'nin maiyetine girmesinin de oldukça büyük payı bulunmaktadır. Atabegin kendisine güvenerek sorumluluk vermesi neticesinde başarı ve tâlih Cemâleddin'in yüzüne gülmüş; Nusaybin,

8 İbnü'l-Ezrak el-Fârikī, Târîhu Meyyâfârikîn ve Âmid: Kısmü'l-Artukıyyîn, nşr. ve çev. Ahmet Savran, Meyyâfârikîn ve Âmid Târihi (Artuklular Klsmı), (Erzurum: Fen-Edebiyat Fakültesi, 1992), 41-42; Süryânî Mihail, Süryani Patrik Mihail' 'in Vakainamesi (1042-1195), çev. Hrant. D. Andreasyan (Ankara: TTK'da bulunan yayımlanmamış nüsha, 1944), II: 94-95; İbnü'l-Esîr, el-Kâmil fi 't-târih, çev. Abdülkerim Özaydın, İslâm Tarihi İbnü'l Esîr, elKâmil fi 't-Târih Tercümesi, (İstanbul: Bahar Yayınları, 1987), X: 508-509; Coşkun Alptekin, The Reign of Zangi (521-541/1127-1146), (Erzurum: Atatürk Üniversitesi Yayınları, 1978), 79; Osman Turan, Doğu Anadolu Türk Devletleri Tarihi, (İstanbul: Ötüken Neşriyat, 2013), 168; Gülay Öğün Bezer, "Zengî, İmâdüddin”, DİA, XLIV, (İstanbul: TDV, 2013), 258-259.

9 Bündârî, Zübdetü'n-Nusra, 192; İbn Hallikân, Vefeyâtü'l-a'yân, V: 143.

10 Irak Selçuklu Devleti atabeglerinden Gündoğdu hakkında bkz. Murat Öztürk, Irak Selçuklu Devleti Atabegleri, (İstanbul: Bilge Kültür Sanat, 2019), 20-24.

11 Bündârî, Zübdetü’n-Nusra, 192; Tülay Yürekli, “Atabeg İmâdeddîn Zengî’nin Şahsî Hayatı”, Nüsha 28, (2009/I), 116-117.

12 Bündârî, Zübdetü'n-Nusra, 192.

13 Bündârî, Zübdetü'n-Nusra, 192; İbn Hallikân, Vefeyâtü'l-a'yân, V: 143.

14 İbnü'l-Esîr, (et-Târîhu'l-bâhir fi'd-devleti'l-Atâbekiyye, nşr. Abdülkādir Ahmed Tuleymât (Kahire: Câmi'atü 'Ayn Şems, 1963), 118) bu tâyinlerin Cemâleddin'in kifâyeti ve namuslu bir devlet adamı olması sebebiyle gerçekleştiğini zikretmiştir. Krş. İbn Hallikân, Vefeyâtü'l-a yân, V: 143; Cengiz Tomar, "İsfahânî, Cemâleddin”, DİA, XXII, (İstanbul, TDV, 2000), 506-507.

15 Devletin malî ve idarî teşkilâtını, hazinesini, vergilerin ve gelirlerin toplanmasını, harcamalar dâhil, en yüksek seviyede kontrol ve teftiş etmekle görevli dîvân hakkında bkz. Erdoğan Merçil, Selçuklular Zamanında Dîvân Teşkilâtı (Merkez ve Eyalet Dîvânları), (İstanbul: Bilge Kültür Sanat, 2015), 76-79; Muharrem Kesik, Selçuklu Müesseseleri ve Medeniyeti, (İstanbul: Bilge Kültür Sanat, 2021), 63-64.

16 İbnü'l-Ezrak, Târîhu Meyyâfârikîn ve Âmid: Kısmü 'l-Artukıyyîn, (nşr. ve çev. Ahmet Savran), 131; İbnü'l-Esîr, Atâbekiyye, s. 118; Bündârî, Zübdetü'n-Nusra, 192; İbn Hallikân, Vefeyâtü'l-a‘yân, V: 143. 
Rahbe gibi şehirlerin idârecilikleri ileride alacağı daha büyük sorumluluklar için tecrübe edinmesini sağlamıştır. Nitekim vâlilik görevlerinin hemen akabinde kendisine tevdi edilen dîvân yöneticiliği onun gitgide yükselen doğru bir çizgide olduğunu kanıtlamaktadır. Bununla beraber görev yaptığı dönemde Nusaybin ve Rahbe'deki faâliyetleri hakkında kaynaklarda mâlûmata rastlamak mümkün olmamıştır. Ancak muhakkak ki başarılı bir idârecilik sergilemesi İmâdeddin Zengî'nin onu Dîvân-1 İşrâf’tan sorumlu kılmasına sebep olmuştur.

Kaynaklarda kendisinden dâima cömertlik vasıflarıyla bahsedilen Cemâleddin el-İsfahânî’nin Musul Atabegi İmâdeddin döneminde sadece günlük yiyeceği ve içeceği kadar erzakı ile idâre ettiği, eline geçen her türlü malı ve parayı da Zengî’nin hazinesine teslim ettiği zikredilir. Bilhassa Dîvân-1 İşrâf' ’n başına geçmesiyle birlikte Cemâleddin'in mülkü yavaş yavaş artmaya başlamış, yaşamı boyunca hayırseverliği ve cömertliğiyle anılacak devlet görevlilerinden olmuştu. ${ }^{17}$ Yetkileri ve mesûliyetleri giderek artan Cemâleddin artık Musul'da İmâdeddin Zengî' den sonraki ikinci adam konumundaydı. ${ }^{18}$

539 (1144) yılında Urfa'yı fethi dolayısıyla Haçlılar üzerinde büyük korku salan İmâdeddin Zengî, Ca 'ber Kalesi'nde şehit edildiğinde (541/1146) halkın ve askerlerin bir kısmı Cemâleddin Muhammed el-İsfahânî'nin de çadırına saldırarak servetini yağmalamaya ve hatta onu öldürmeye teşebbüs etmiştir. Kaynaklarda bu süreçte Cemâleddin'in dîvânın başında bulunduğu, bütün devlet işlerini yönettiği bilgisi geçmektedir. ${ }^{19} \mathrm{Bu}$ kıskanç düşüncelerle harekete geçenler ve atabegliği parçalamak isteyenler Cemâleddin'in yanında duran ve müdâfaasını üstlenen bazı emîrlerin gayretleriyle geri püskürtüldüler. ${ }^{20}$ Cemâleddin'in nüfuzunun nasıl arttığını ve Musul Atabegliği içerisinde dostlarını kadar hasımlarının da bulunduğunu gösteren bu hâdiselere tanık olan İbnü'l-Ezrak (ö. 577/1181'den sonra) Cemâleddin Muhammed el-İsfahânî ve diğer görevlilere karşı yapılan harekât esnâsında saldırganların, İmâdeddin Zengî'nin atabegliğini üstlendiği Irak Selçuklu Meliki Alparslan b. Mahmûd'u destekleyici tutumları üzerinde durmuştur. ${ }^{21}$ Ancak Melik Alparslan muhtemelen tüm kontrolü eline geçireceğini

17 Bündârî, Zübdetü'n-Nusra, 192; İbn Hallikân, Vefeyâtü'l-a'yân, V: 143.

18 Ali Sultan Abbâs, "Vezîru Atabeki Mevsıl Cemâleddin el-İsfahânî (521-559/1127-1163),” Moss 11 (2006), 36.

19 İbnü'l-Ezrak, (Târîhu Meyyâfârikîn ve Âmid: Kısmü'l-Artukıyyîn, (nşr. ve çev. Ahmet Savran), 80-81; a. mlf., Târîhu Meyyâfârikîn ve Âmid, İngilizceye kısmî çev. C. Hillenbrand, A Muslim Principality in Crusader Times the Early Artuqid State (İstanbul: Nederlands Historisch-Archaeologisch Instittuut 1990), 117) İmâdeddin Zengî'nin öldürülmesinden sonraki saldırıların yaşandığg esnâda Cemâleddin'in vezir olduğunu vurgulamaktadır. Bununla birlikte İbnü'l-Ezrak yine eserinde (Târîhu Meyyâfârikîn ve Âmid: Kısmü'l-Artukıyyîn, (nşr. ve çev. Ahmet Savran), 81; Târîhu Meyyâfârikîn ve Âmid: Kısmü’l-Artukıyyîn, (İngilizce kısmî çev. C. Hillenbrand), 118) İmâdeddin Zengî'nin İstifâ dîvânında "Müstevfì" olarak görev yapmıș Cemâleddin'in, Atabeg'in oğlu Seyfeddin Gazi tarafından vezir tâyin edildiğini zikretmiştir. Yine aynı eserde (nşr. ve çev. Ahmet Savran), 131, Atabeg Zengî devrinde Dîvân-1 İşrâf'ın başında müşrif olarak görev yaptığı da vurgulanmıştır. Bündârî (Zübdetü'nNusra, 192), vezir olduğunu belirtmiştir. Krş. İbnü'l-Esîr, el-Kâmil, XI: 106; İbn Hallikân, Vefeyâtü'l-a'yân, V: 143-144.

20 İbnü'l-Ezrak, Târîhu Meyyâfârikîn ve Âmid: Klsmü'l-Artukıyyîn, (nşr. ve çev. Ahmet Savran), 80-81; Târîhu Meyyâfârikîn ve Amid: Kısmü'l-Artukıyyîn, (İngilizce kısmî çev. C. Hillenbrand), 117; İbn Hallikân, Vefeyâtü'l-

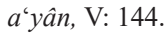

21 İbnü'l-Ezrak, Târîhu Meyyâfârikîn ve Âmid: Kısmü'l-Artukıyyîn, (nşr. ve çev. Ahmet Savran), 81; Târîhu Meyyâfârikîn ve Âmid: Kısmü'l-Artukıyyîn, (İngilizce kısmî çev. C. Hillenbrand), 117; Öztürk, Irak Selçuklu Devleti Atabegleri, 61. 
plânlarken melikin İmâdeddin Zengî’nin oğullarının hâkimiyetini kabul edeceğinden şüphe duyan Cemâleddin, duruma müdâhale etmiştir. Diğer emîrlerle ve İmâdeddin Zengî’nin kumandanlarından Begteginliler de denilen Erbil Atabegliği'nin de kurucusu Zeyneddin Ali Küçük (ö. 562/1167) ile haberleşerek İmâdeddin Zengî'nin en büyük oğlu I. Seyfeddin Gazi’nin süratle Musul Atabegliği'nin başına getirilmesinin yerinde olacağına karar vermişlerdi. ${ }^{22}$ Cemâleddin el-İsfahânî, Irak Selçuklu melikinin Musul Atabegliği'nin geleceği için tehlike arz ettiğini fark etmiş, süratle bu hususta tedbir almıştır. İmâdeddin Zengî, Irak Selçuklu Devleti Sultanı tarafından oğluna atabeg olarak tâyin edildiği hâlde Cemâleddin el-İsfahânî melikin otoriteyi tesis etmesine izin vermemiş, aksine Zengî hânedanının çıkarlarını ve kendi statüsünü korumaya gayret sarf etmiştir.

I. Seyfeddin Gazi ise o sırada Irak Selçuklu Sultanı Mes'ûd'un (529-547/1134-1152) kendisine iktâ ettiği Şehrizûr' da ${ }^{23}$ bulunuyordu. Bu esnâda Cemâleddin, hâdiselerin başlangıcında aralarındaki uzlaşmazlıklar yüzünden kendisinden çekinerek saklanmış olsa da atabegliğin geleceği açısından işbirliği içerisinde olmayı uygun gördüğü Emîr-i hâcib Selâhaddin Muhammed el-Yağısıyanî ile uzlaşma yoluna girdi. İki devlet adamı birbirlerine yemin ettiler ve aralarındaki husumetleri unutarak müttefik olmaya karar verdiler. ${ }^{24}$ Irak Selçuklu melikini ise içki ve eğlence meclisleriyle oyalamanın yolunu bularak hep birlikte Rakka'ya geçme hususunda meliki iknâ ettiler. Ayrıca Ali Küçük'e de haber gönderip Şehrizûr'da bulunan emîrden süratle Musul'a gelmesini istediler. Cemâleddin öte taraftan diğer emîrlerden de I. Seyfeddin Gazi adına destek almayı ihmâl etmiyordu. Cemâleddin el-İsfahânî’nin propagandaları askerler üzerinde de etkili olmuş, melikin yanından ayrılarak Musul'a yürümüşler, I. Seyfeddin Gazi'nin tarafına geçmeye başlamışlardı. ${ }^{25}$

Melik Alparslan ve Cemâleddin el-İsfahânî Rakka'da birkaç gün kaldıktan sonra Mâkisin ${ }^{26}$ ardından da Sincâr'a geçtiklerinde I. Seyfeddin Gazi ve beraberindeki devlet adamları, Melik Alparslan'dan çok daha önce Musul'a varmışlardı. Sincâr'a vardıkları zaman Cemâleddin, Sincâr dizdârına haber gönderip Melik Alparslan'ın Sincâr'a hâkim olmayı istemesi durumunda ona şöyle bir mesaj iletmesini istedi: "Ben senin memlükünüm, fakat Musul'a tâbiyim. Sen ne zaman Musul'a hâkim olursan Sincâr'l sana o vakit teslim ederim. ” Bunun üzerine Melik Alparslan süratle Musul'a doğru gitmeye karar verdiyse de yanında az sayıda asker kaldığı için Cemâleddin'in tavsiyesiyle Musul yakınlarındaki Beled'e doğru yöneldiler. Cemâleddin, I. Seyfeddin Gazi'nin artık Musul'a gelmiş olduğunu öğrendi ve ona haber göndererek Melik Alparslan'ın yanında az sayıda asker bulunduğunu bildirdi. I. Seyfeddin Gazi hemen bir kısım

22 Öztürk, Irak Selçuklu Devleti Atabegleri, 61; Gök, "Musul'da Yaşamış Seçkin Bir Sima," 514.

23 Kuzey Irak'taki tarihî bölge hakkında bkz. Yâkūt el-Hamevî, Mu 'cemü'l-büldân, (Beyrut: Dâru Sâdır, 1977/1397), III: 375-376; Ahmet Gündüz, "SSehrizor”, DİA, XXXVIII, (İstanbul: TDV, 2010), 473-475.

24 İbnü'l-Esîr, Atâbekiyye, 84-85; İbn Vâsıl, Müferricü 'l-kürûb fi ahbâri Benî Eyyûb, nşr. Cemâleddin eş-Şeyyâl (Kahire: 1953-1960), I: 107.

25 İbn Vâs1, Müferricü’l-kürûb, I: 107-108.

26 Rahbe yakınlarında Habur Nehri'ne kıyısı olan yerleşim yeri hakkında bkz. Yâkūt, Mu 'cemü 'l-büldân, V: 43; Strange, Doğu Hilafetinin Memleketleri, 139. 
kuvvetlerini Melik Alparslan'ın üzerine gönderdi ve onu derdest ettirerek Musul Kalesi'nde hapsedilmesini sağladı. Nitekim I. Seyfeddin Gazi böylece ülkeye hâkim oldu. Emîrler ve devlet adamları nihâyet onu Musul Atabegliği' nin başına geçirmeyi başarmışlardı. ${ }^{27}$ Cemâleddin elİsfahânî'nin yoğun gayretleriyle Musul üzerindeki Selçuklu hânedanının gölgesi de ortadan kalkmış oldu. ${ }^{28}$ Bununla beraber Cemâleddin Muhammed el-İsfahânî, I. Seyfeddin Gazi'nin Musul'da atabeg olarak başa geçmesi hususunda Irak Selçuklu Sultanı Mes'ûd'a da ricâda bulunmuş ve sultandan İmâdeddin Zengî'nin vârisi olarak I. Seyfeddin Gazi’nin hâkimiyetini onaylamasını da istemişti. Sultana kıymetli hediyeler, hil'atlar gönderildi ve en nihâyetinde İmâdeddin Zengî’nin büyük oğlu I. Seyfeddin Gazi, Musul Atabegi olarak ilân edildi. ${ }^{29}$

İmâdeddin Zengî'nin oğullarından Nûreddin Mahmud b. Zengî (541-569/1146-1174) ise vefatı esnâsında babasının yanında bulunuyor iken bazı emîrlerle Halep'e gelerek şehre hâkim olmuş; burada kalmayı tercih etmiştir. Böylece İmâdeddin Zengî’nin devleti bir bakıma Musul ile Halep ve Dımaşk Atabegliği olarak ikiye bölünmüştür. I. Seyfeddin Gazi işleri idâre ve devletini muhâfaza etmek maksadıyla Selâhaddin el-Yağısıyanî’yi de kardeşinin yanına göndermiştir. ${ }^{30}$

Atabeg İmâdeddin Zengî'nin vefatı ve bu saldırı teşebbüslerini önlemesinin ardından Cemâleddin Muhammed el-İsfahânî'nin nüfuzunun daha da arttı̆̆ı dikkat çekmektedir. Belirtmekte fayda bulunmaktadır ki, I. Seyfeddin Gazi ülke yönetimini eline alınca Cemâleddin'i kendisine vezir olarak tâyin etti, ${ }^{31}$ ordu komutanlığ 1 ve nâiblik görevine getirilerek I. Seyfeddin Gazi'nin hizmetine giren Ali Küçük de vezirlik ve diğer devlet işlerinde Cemâleddin'e her dâim yardım sözü verdi. Böylece bu iki devlet adamı Musul Atabegliği’nin bütün işlerini beraberce iş birliği içerisinde yürütmeye başlamışlard ${ }^{32}$ Cemâleddin el-İsfahânî'nin I. Seyfeddin Gazi'nin Musul Atabegi olması hususunda gösterdiği siyasî faâliyetler ve aldı̆̆ 1 tedbirler ile istikbalini de sağlamlaştırdığı görülmektedir. Nihâyetinde kendisine bu derece yardımlarda bulunan bir devlet görevlisini Musul Atabeginin muhakkak ki onurlandırmayı ihmâl etmemesi ve yüksek mevkilere gelmesine imkân sağlaması tabiidir.

544 (1149) yılında I. Seyfeddin Gazi bir süredir devam eden kulunç hastalığından dolayı vefat ettiğinde yerine Vezir Cemâleddin ve baş kumandan Zeyneddin Ali Küçük'ün gayretleriyle Musul'da ikamet eden kardeşi Kutbeddin Mevdûd getirildi ve bu olay neticesinde Cemâleddin bir

27 İbnü'l-Esîr, el-Kâmil, XI: 106; Coşkun Alptekin, Dimaşk Atabegliği (Tog-Teginlilier), (İstanbul: Marmara Üniversitesi Yayınları, 1985), 133.

28 Gök, Musul'da Yaşamış Seçkin Bir Sima," 515.

29 İbnü'l-İbrî, Abû'l-Farac Tarihi, çev. Ömer Rıza Doğrul (Ankara: TTK, 1999), II: 383; Alptekin, Dimaşk Atabegliği, 133; Gök, Musul Atabeyliği, 60, 120.

30 İbnü'l-Esîr, el-Kâmil, XI: 106; Alptekin, Dimaşk Atabegliği, 133; Bahattin Kök, "Nûreddin Zengî, Mahmud", DİA, XXXIII, (İstanbul TDV, 2007), 259.

31 İbnü'l-Ezrak, Târîhu Meyyâfârikîn ve Amid: Klsmü'l-Artukıyyîn, (nşr. ve çev. Ahmet Savran), 81; a. g. e., (İngilizce kısmî çev. C. Hillenbrand), 118; İbnü'l-Esîr, Atâbekiyye, 119; İbn Hallikân, Vefeyâtü'l-a'yân, V: 144.

32 Bündârî, Zübdetü'n-Nusra, 192; Gök, Musul Atabeyliği, 120. 
kez daha vezirliğe tâyin edildi. ${ }^{33}$ Öte yandan emîrler Halep’te bulunan I. Seyfeddin Gazi'nin bir diğer kardeşi Nûreddin Mahmud'un nasıl bir tavır alacağı hususunda endişeliydiler. Kutbeddin Mevdûd'un görevlendirdiği bazı emîrler Nûreddin Mahmud'un muvâfakatini almak üzere Halep'e geldiler. ${ }^{34}$ Nûreddin Mahmud b. Zengî ise Musul yönünde ilerlemeye başlamış, hatta bu sırada Sincâr'a hâkim olmuş; bütün kuvvetlerini kardeşine karşı mücâdele için hazırlamışken, Musul kuvvetleri de Sincâr'a doğru harekete geçmişti. Ancak Vezir Cemâleddin'in gayretleriyle meseleyi sulh yolu ile çözmeye karar vermişlerdir. Vezir Cemâleddin'in şâyet bir savaş çıkacak olursa Irak Selçuklu Sultanı Mes ‘ûd'un duruma müdâhale edebileceğini ve Müslümanlar adına Haçlılarla mücâdele eden Nûreddin ile muhârebe etmenin de doğru olmayacağını belirtmesi neticesinde Nûreddin Mahmud ile Kutbeddin Mevdûd arasında anlaşma hasıl oldu. Bu anlaşmayla Nûreddin Mahmud, Sincâr'1 kardeşine teslim etti; Urfa, Rahbe, Rakka, Hıms gibi Musul Atabegliği'ne âit şehirler de Kutbeddin Mevdûd tarafından kendisine verildi. Böylece Nûreddin Mahmud'un Suriye bölgesindeki topraklarda Kutbeddin Mevdûd'un da Sincâr'1 elinde tutarak Urfa hâriç el-Cezîre bölgesindeki topraklarda hüküm sürmesi kararlaştırılmış ve kardeşi ile olan anlaşmazlıkları çözen Nûreddin Mahmud da dikkatini daha güneye Dımaşk'a yöneltir olmuştu. ${ }^{35}$ Görüldüğü üzere Cemâleddin İsfahânî’nin ustaca siyâseti, gayretleri ve barış tavsiyeleri, Zengîlerin birbirlerine karşı girişecekleri iç mücâdeleleri önlemiştir. Son derece akıllı bir şekilde hareket eden vezir, Zengî hânedanının Musul'da hükümranlığını sürdürebilmesi için birikimini bu uğurda sarf etmiştir. Kendi kişisel iktidarının devamı için de hânedanın Musul kolunun idâme etmesi gerektiğinin farkında olarak I. Seyfeddin Gazi'nin âni vefatının ardından Halep'te bulunan Nûreddin Mahmud Zengî yerine Musul'da bulunan Kutbeddin Mevdûd'u tercih etmiştir. ${ }^{36}$

Nûreddin Mahmud b. Zengî, Halep ve ardından da Dımaşk'ta hüküm sürerken 554 (1159) yılında şiddetli hastalanmış; hatta öldügü yönünde söylentiler dahi yayılmaya başlamıştı. Adamlarına kendisinden sonra akıllı, îtikat sahibi, dindâr olması gibi iyi özelliklerini vurgulayarak Musul hâkimi Kutbeddin Mevdûd'a itaat etmelerini tembih etmiş ve durumunu anlatan mektubunu da kardeşi Mevdûd'a elçileri vasıtasıyla göndermişti. Elçiler mektuplarının cevaplarıyla geri döndüklerinde ise Nûreddin Mahmud Zengî yavaş yavaş iyileşmeye başlamıştı. Öte taraftan Musul Atabegi çoktan Dımaşk’a gitmek üzere ordusuyla birlikte yola çıkmış; kardeşinin sağlıklı olduğuna dâir haberler kendisine ulaşınca da durumu yerinde incelemesi için veziri Cemâleddin Muhammed el-İsfahânî'yi görevlendirerek kendisi de Musul'a geri dönmüştü. Vezir 8 Safer 554 tarihinde (1 Mart 1159) süslü elbiseler içinde Dımaşk'a ulaştığında

33 İbnü'l-Kalânisî, Zeylü Târîhi Dımaşk, nşr. H. F. Amedroz (Beyrut: Matbaatü'l-âbâi'l-Yesûiyyîn, 1908), 307; İbnü'l-Ezrak, Târîhu Meyyâfârikîn ve Âmid: Kısmü'l-Artukiyyîn, (nşr. ve çev. Ahmet Savran), 89; Târîhu Meyyâfârikîn ve Âmid: Kısmü'l-Artuklyyîn, (İngilizce kısmî çev. C. Hillenbrand), 130; İbnü’l-Esîr, el-Kâmil, XI: 126-127; İbn Vâs1, Müferricü 'l-kürûb, I: 118-119; İbn Hallikân, Vefeyâtü'l-a'yân, V: 145; Alptekin, Dimaşk Atabegliği, 147.

34 Alptekin, Dimaşk Atabegliği, 147.

35 İbnü'l-Esîr, el-Kâmil, XI: 127, 128; İbn Vâs1l, Müferricü 'l-kürûb, I: 120; Alptekin, Dimaşsk Atabegliği, 147; Gök, Musul Atabeyliği, 81-83; Bahattin Kök, "Mevdûd b. İmâdüddin Zengî”, DİA, XXIX, (Ankara: TDV, 2004), 430.

36 Gök, Musul'da Yaşamış Seçkin Bir Sima," 515. 
kalabalık topluluklar onu karşılamak üzere yola çıkmışlardı. Nûreddin Mahmud'un huzurunda hüsn-ü kâbul görmüş; beraber kararlar almışlardı. Hatta gelişmelerin akabinde Nûreddin Mahmud da aralarındaki dostluğun bir göstergesi olarak kardeşi ile görüşmeleri için yakın adamlarını Cemâleddin el-İsfahânî ile beraber göndermişti. ${ }^{37}$

Vezir Cemâleddin, Müslüman hâkimlerin birlikte ittifak ederek Gürcülerle yaşadıkları mücâdelelerde de diplomatik bir rol üstlenmiştir. Gürcü Kralı III. Giorgi (551-579/11561184), 556 (1161) yılında Selçuklu Devleti'ne bağlı Şeddâdîler'in ${ }^{38}$ topraklarını yağmalamış ve sonrasında da Ahlat yakınlarındaki müstahkem Ani şehrini ele geçirmişti. Gürcüler Ani'yi kuvvet zoruyla almış, kenti yağmalayıp çok sayıda ganîmet ele geçirerek şehirde bulunan Ermeni ve Türklerden yaklaşık 1.000 kişiyi de katletmişlerdir. ${ }^{39}$ Gürcülerin Ani’yi işgal etmesi İslâm dünyasında büyük yankı uyandırdı. Ahlatşah II. Sökmen, Erzurum Emîri İzzeddin Saltuk, Erzen ve Bitlis Emîri Fahreddin Devletşah, Mardin ve Artuklu Emîri Necmeddin Alpı ve diğer bazı Türk emîrleri Gürcülere karşı bir sefere çıkmaya karar verdiler. Ancak mücâdeleler esnâsında pek çok Müslüman öldürüldüğü gibi binlercesi de esir düşmüş, ordunun bütün ağırlıklarına, sayısız ganîmet ve servete sâhip olan Gürcüler de şehirden ihtiyaçlarını temin ettikten sonra büyük bir sevinç içerisinde ülkelerine geri dönmüşlerdir. ${ }^{40}$ Yaşanan ağır mağlûbiyet üzerine Vezir Cemâleddin devreye girmiş; Gürcü Kralı'na haber yollayarak alıkoyduğu kumandanların serbest bırakılması hususunda ricâlarda bulunmak için elçi göndermiştir. Vezirin teşebbüsleri neticesinde Gürcü Kralı esirlerin büyük çoğunluğunu herhangi bir bedel talep etmeden serbest bırakmıştır. ${ }^{41}$ Bu hâdise Cemâleddin el-İsfahânî'nin yalnızca Musul Atabegliği’nin içişlerinde kuvvetli rol oynamadığını; devletler arası siyâsette de nüfuz sâhibi bir şahsiyet olduğunu göstermektedir.

Vezir Cemâleddin'in İsfahân'daki Şafîilerin reisliğini yapan ve ilmî faâliyetlerde bulunan Hucendî Âilesi'yle de yakînen temasları da olmuştur. Irak Selçuklu Devleti atabeglerinden Boz-aba (ö. 542/1147-1148) ${ }^{42}$ Sultan Mes 'ûd'a karşı isyan etmiş; hatta aynı zamanda damadı da olan Melik Muhammed b. Mahmûd'u (547-554/1153-1159) tahta çıkarma teşebbüsünde bulunmuştu. Bu esnâda devlet ricâlinin bir kısmı Boz-aba'yı bir kısmı ise Sultan Mes'ûd'u desteklemekteydi. Bu mücâdeleler sırasında payitahta doğru ilerlemek isteyen Boz-aba yanındaki

37 İbnü'l-Kalânisî, Zeylü Târîhi Dımaşk, 356.

38 Şeddâdîler hakkında bilgi için bkz. Ahmed Kesrevî, Şehriyârân-ı Gumnâm, (Tahran: Müessese-i İntişârât-i Nigâh, 2535 şş), 255-316; Nevzat Keleş, Şeddâdîler (951-1199) Ortaçă̆'da Bir Kürt Hanedanı, (İstanbul: Bilge Kültür Sanat, 2016); Gülay Öğün Bezer, "Şeddâdîler”, DİA, XXXVIII, (İstanbul: TDV, 2010), 409-411.

39 Urfalı Mateos, Urfalı Mateos Vekayi-Nâmesi (952-1136) ve Papaz Grigor'un Zeyli (1136-1162), çev. Hrant D. Andreasyan (Ankara: TTK, 2000), 331; İbnü'l-Esîr, el-Kâmil, XI: 228; Keleş, Şeddâdîler, 292.

40 İbnü'l-Kalânisî, Zeylü Târîhi Dımaşk, 361; İbnü'l-Ezrak, Târîhu Meyyâfârikîn ve Âmid: Klsmü'l-Artukıyyîn, (nşr. ve çev. Ahmet Savran), 127; İbnü'l-Esîr, el-Kâmil, XI: 228; İbnü'l-İbrî, Abû 'l-Farac Tarihi, II: 399; M. F. Brosset, Gürcistan Tarihi (Eski çă̆lardan 1212 yılına kadar), çev. Hrant D. Andreasyan, haz. Erdoğan Merçil (Ankara: TTK, 2003), 343-349.

41 İbnü'l-Kalânisî, Zeylü Târîhi Dımaşk, 361; İbnü'l-Ezrak, Târîhu Meyyâfârikîn ve Âmid: Kısmü'l-Artukıyyîn, (nşr. ve çev. Ahmet Savran), 127-128; İbnü'l-İbrî, Abû'l-Farac Tarihi, II: 399; Gök, Musul Atabeyliği, 123.

42 Atabegin siyasî faâliyetleri hakkında bkz. Öztürk, Irak Selçuklu Devleti Atabegleri, 91-100. 
birlikler ile İsfahân'a gitmiş orada bulunan Şafiîlerin reisi Sadreddîn Ebû Bekir Muhammed el-Hucendî (ö. 552/1157-1158) şehrin kapılarını açtırmış, halkı onunla birleşmeye teşvik etmiştir. ${ }^{43}$ Yaşanan gelişmelerin akabinde Boz-aba Sultan Mes 'ûd tarafından mağlûp edilerek öldürülse de Irak Selçuklu hükümdarı, Boz-aba'ya meyl edenleri cezalandırmaya devam etmiş; İsfahân'a da askerlerini göndermişti. İşte bu sırada Hucendîlerin medreseleri yağmalanmış onlar da çâreyi İsfahân'dan ayrılmakta bulmuşlardır. Nitekim Sadreddîn Muhammed ve kardeşi Cemâleddin Mahmûd Musul'a gittiklerinde Vezir Cemâleddin el-İsfahânî tarafindan izzet-i ikramla karşılanmışlardır. Vezir, Hucendîlere büyük hürmet göstermiştir. Cemâleddin Mahmûd kısa süre sonra Musul'dan ayrılarak hacca gitmiş, Sadreddîn Muhammed ise bir süre Cemâleddin'in yanında kaldıktan sonra vezirin cömertliğini gösteren çokça hediyeyle birlikte İsfahân'a geri dönmüştür. Hatta bu durumu şu beyiti ile tavsif etmiştir: "Kapına yalnız geldim, senin nimetlerin sâyesinde kafile olarak geri döndüm. "44 Vezirin yardımları ve yapmış olduğu iyilikleri Hucendîler tarafından unutulmamış; âile ile akraba olan Muhammed el-Kassâm tarafindan Cemâleddin el-İsfahânî istikbalde tutuklandığında bunun haysiyetsiz devlet adamlarının işi olduğu belirten uzunca bir mektup yazılmış ve İsfahân'da her zaman pek çok dostu bulunduğuna dâir de vezire güvence verilmiştir. ${ }^{45}$

Vezir Cemâleddin' in başarıları atabeglik nezdindeki önemi rakiplerinin harekete geçmesine ve onu gözden düşürmek istemelerine sebep olmuştur. Çok geçmeden aleyhine yapılan faâliyetler de netice vermeye başlamıştır. Bu kişiler Cemâleddin Muhammed el-İsfahânî’nin devlet malını kendi şahsî menfaati adına alarak har vurup harman savurduğunu söylüyorlard1 $1{ }^{46} \mathrm{Bu}$ durum vezirin Musul'dan çok uzakta olan bölgelerde bile yapmış olduğu hayırlar, sadakalar, îmar ve onarım faâliyetlerine yapılan ciddî harcamaların devlet ricâlinin tepkisini çektiğini, bu masraflara harcanan meblağların kaynağı hakkında rahatsızlık duyduklarını göstermektedir. Atabeg Kutbeddin Mevdûd'u da te'sirleri altına alarak Musul Atabegi'ni veziri aleyhine etkilemeyi başardılar. Kutbeddin Mevdûd, Vezir Cemâleddin'in iktâsını çok fazla bularak ve elde ettiği üstünlükten bıkarak onu nâib ve ordu komutanı Zeyneddin Ali Küçük vasıtasıyla

43 Hüseynî, Ahbârü'd-Devleti's-Selçukıyye, çev. Necati Lugal (Ankara: TTK, 1943), 83; Bündârî, Zübdetü'n-Nusra, 199; Öztürk, Irak Selçuklu Devleti Atabegleri, 98.

44 Bündârî, (Zübdetü'n-Nusra, 201-202) Hucendî kardeşlerin sultan tarafindan da affedildiklerini, kendilerine hil'âtlar gönderildiğini, İsfahân reisliğinin Sadreddîn Muhammed el-Hucendî’ye yeniden iâde edildiğini zikreder. Ayrıca bkz. David D. Guédy, Iranian Elites and Turkish Rulers A History of Isfahān in the Saljūq Period, (London-New York: Routledge, 2010), 244-245.

45 Guédy, Iranian Elites, 245.

46 İbnü'l-Esîr, Atâbekiyye, s. 119. 
558 yılı Receb ayında (Haziran-Temmuz 1163) tutuklatarak Musul Kalesi'nde hapsettirdi. ${ }^{47}$ Veziri tutuklayan devlet görevlisinin aralarında geçmişten gelen bir ittifaka rağmen bizzat Zeyneddin Ali Küçük olması da dikkati çekmektedir. Kutbeddin Mevdûd'un başarılı idâreciliğine rağmen vezirine karşı birazdan bahsedileceği üzere büyük paralar harcayarak farklı coğrafî bölgelerde çeşitli projeler gerçekleştirmesi ve keyfî davranışları sebebiyle artık sabrının tükendiği anlaşılmaktadır. Nitekim her dâim Zengî hânedanını koruyan vezirini Zeyneddin'in adamlarından gelen telkinlerin de etkisiyle tutuklatmıştır. 559 yılı Şâban (Haziran-Temmuz 1164) ya da Ramazan ayı (Ağustos 1164) içerisinde ${ }^{48}$ Cemâleddin Muhammed el-İsfahânî yaklaşık bir senedir tutuklu bulunduğu kalede vefat etmiştir.

İbnü'l-Esîr'in Cemâleddin el-İsfahânî'nin hapis sürecinde ona hizmet eden Ebü'l-Kâsım adlı bir sûfiden aktardığı mâlûmata göre; Cemâleddin hapishânede zâhîdâne bir hayat sürdürmüş ve “Ben vezâret makâmından kabre gitmekten dâima korkardım!’ demiştir. Bir gün hastalanmış ve Ebü'l-Kâsım'dan eğer beyaz bir güvercin gelirse kendisine haber vermesini istemiştir. Ebü'lKâsım kendi kendine: "Galiba bu adam aklını şaşırdı!” diye düşünürken Cemâleddin ertesi gün yine o beyaz güvercini sormuş; bu esnâda Ebü'l-Kâsım'ın benzerini hiç görmediği beyaz bir güvercin yere düşmüştür. Hemen: “Kuş geldi!” diyerek haber verince vezir bu söze sevinmiş ve: "Hak geldi!" diyerek ölünceye kadar şehâdet getirmeye ve Allah Teâlâ'yı zikretmeye başlamış, çok geçmeden Cemâleddin ölünce bu güvercin de uçup gitmiştir. ${ }^{49}$ Musul'da Fethü'lKerâmî (فتح الكر امي) adlı bir sûfînin mezarının yanı başına geçici olarak defnedilen Cemâleddin Muhammed el-İsfahânî'nin cenâze törenine fakirler, dullar, yetimlerden müteşekkil kalabalık bir topluluk katılmış, insanlar o güne kadar görülmemiş çığlıklarla feryat edip ağlayarak âdeta sesleriyle gökyüzünü inletmişlerdir. ${ }^{50}$

Cemâleddin Muhammed el-İsfahânî rivâyete göre Nûreddin Mahmud b. Zengî’nin önemli kumandanlarından Esedüddîn Şîrkûh (ö. 564/1169) ile daha önceden vasiyeti hususunda anlaşmıştı. Buna göre hangisi daha önce vefat ederse sağ kalan vefat edenin naâşını Medine’ye

47 İbnü’l-Esîr, (Atâbekiyye, 119) hâdiselerden Zeyneddin Ali Küçük'ün maiyetindeki adamlarının sorumlu olduğunu, Cemâleddin el-İsfahânî'yi sevmediklerini, Ali Küçük'ün huzurunda veziri sıklıkla eleştirdiklerini ancak Ali Küçük'ün bu duruma izin vermeyip erkânını kötü sözlerden men ederek vezir ile aralarında bir ittifakın bulunduğunu zikretmiştir. Bu kişiler ısrarla Zeyneddin'in yükselişinin ancak Cemâleddin'in gözden düşürülmesine bağlı olacağını vurgulamaya devam etmişlerdir. Zeyneddin Ali Küçük ise vezirin tutuklanmasına onay verdiği ve bu hasetçilere inandığı için pişmanlık çekmiştir. İbnü’l-Ezrak (Târîhu Meyyâfârikîn ve Âmid: Kısmü'l-Artukıyyîn, (nşr. ve çev. Ahmet Savran), 133) vezirin Zeyneddin Ali Küçük vasıtasıyla tutuklandığını kaydetmiştir. Krş. İbn Hallikân, Vefeyâtü'l-a'yân, V: 145, Gök, Musul Atabeyliği, 126.

48 İbnü’l-Ezrak (Târîhu Meyyâfârikîn ve Âmid: Kısmü'l-Artukıyyîn, (nşr. ve çev. Ahmet Savran), s. 133), 559 yılı Ramazan ayının son 10 gününe kadar (Ağustos 1164) hapiste kalıp ardından vefat ettiğini kaydeder. İbnü’l-Cevzî (el-Muntazam fî târîhi'l-mülûk ve 'l-ümem, nşr. Muhammed Abdülkādir Ahmed Atâ ve Mustafa Abdülkādir Atâ (Beyrut: Dârü'l-kütübi'l-ilmiyye, 1992), XVIII: 161) 559 yılı Ramazan ayında (Ağustos 1164) vefat haberinin ulaştığını; İbnü'l-Esîr (el-Kâmil, XI: 249) 559 yılının Şâban ayında (Haziran-Temmuz 1164); İbn Hallikân (Vefeyâtü'l-a'yân, V: 145), 559 yılı Ramazan ayının son on gününden birinde (Ağustos 1164) bazı kaynaklara göre de 559 yılı Şâban ayı içerisinde (Haziran-Temmuz 1164) vefat ettiğini ve Musul'da defnedildiğini zikreder.

49 İbnü'l-Esîr, el-Kâmil, XI: 249; İbnü'l-Esîr, Atâbekiyye, 127.

50 İbnü'l-Ezrak, Târîhu Meyyâfârikîn ve Âmid: Klsmü'l-Artuklyyîn, (nşr. ve çev. Ahmet Savran), s. 133; İbnü'l-Esîr, el-Kâmil, XI: 250; İbn Hallikân, Vefeyâtü'l-a'yân, V: 145. 
götürerek orada inşâ ettirdiği türbede defnedecekti. Cemâleddin bunu Ebü'l-Kâsım'a anlatarak şâyet ölürse Esedüddîn Şîrkûh'un yanına giderek bu durumu ona hatırlatmasını ve gerekli düzenlemeleri yapmasını istemişti. Ebü'l-Kâsım, Esedüddîn Şîrkûh ile görüşmüş; ondan mütevâzî bir şekilde sadece cenâzeyi ve kendisini taşıyacak develer vermesini istemişse de Cemâleddin gibi bir vezirin bu şekilde götürülmemesi gerektiğini belirten Şîrkûh, Cemâleddin'e vekâleten hac edecek ve tabutu önünde Kur'an okuyacak bir topluluğun da masraflarını karşılamış, yol boyunca sadakalar dağıtılması için de para vermişti. ${ }^{51}$

Hazırlıklar tamamlandıktan sonra naâşı Musul'daki kabrinden alınarak vasiyet ettiği üzere Tikrît, Bağdât, Hille üzerinden Mekke'ye nakledilmek üzere kafile eşliğinde yola çıkmıştır. Yol boyunca salâlar okunmuş, cenâze namazları kılınmıştır. Cemâleddin'in tabutu Kâbe etrafında tavaf ettirilmiş ardından cenâzesi Medine'ye getirilmiştir. Hz. Peygamber'in kabri de tavaf edildikten sonra Medine eşrafı tarafından omuzlarda taşınarak Medine'nin güney doğusundaki Cennetü'l-Bakī' Kabristanı ile Resûlullah'ın kabri arasında yer alan ve Mescid-i Nebevî’ye çok az bir mesâfede bulunan, evvelce kendisi için yaptırmış olduğu ribâtta defnedilmiştir. ${ }^{52}$ Hayatta iken hac farîzasını yerine getirememiş olan Cemâleddin'e vefatında bir başkası için izin verilmeyecek şekilde merâsimler tertip edilmiş, Hz. Peygamber'in kabrine oldukça yakın bir yerde defnedilerek onurlandırılmıştır. ${ }^{53}$

Vezir Cemâleddin Muhammed el-İsfahânî’nin Celâleddin nâmıyla tanınan oğlu ise babası gibi Musul'un önde gelen devlet adamlarından biri olarak Kutbeddin Mevdûd'un oğlu II. Seyfeddin Gazi (565-576/1170-1180) döneminde vezirlik görevini üstlenmiş; ayrıca edip ve şâir olarak bir dîvan yazmış; hatta risâleleri İbnü'l-Esîr'in kardeşlerinden Mecdüddin (ö. 606/1210) tarafından bir araya getirilmiştir. ${ }^{54}$

\section{b) Hayırseverlik Faâliyetleri ve Amme Hizmetleri}

I. Seyfeddin Gazi'nin vezirliğini yaptığı dönemden îtibâren artık "el-cevâd” (cömert) olarak tanınan Cemâleddin el-İsfahânî, hayır işleri için muazzam harcamalar yapmaya ve âlimleri korumaya başlamıştır. Hatta henüz vezirlik görevi tevdî edilmeden önce de ilim erbâbına ehemmiyet vermiştir. İbnü'l-Esîr'in babass ${ }^{55}$ Rakka'da henüz vezir olmadan önceki döneminde Cemâleddin'i yanında fikıh âlimi bir zât ile konuşurken görmüştü. Âlim birkaç gün boyunca Cemâleddin ile sık sık görüşmüş, ardından bu ziyaretler kesilmişti. O zâtın gittiği kendisine söylendiğinde bu durum Cemâleddin'e çok zor gelmişti. Kısa süre sonra yeniden âlimi sormuş ve onun Mardin tarafında olduğunu öğrenince Cemâleddin o adama bir hil‘ât

51 İbnü'l-Esîr, el-Kâmil, XI: 250; İbnü'l-Esîr, Atâbekiyye, 127.

52 İbnü'l-Ezrak, Târîhu Meyyâfârikîn ve Âmid: Klsmü'l-Artukıyyîn, (nşr. ve çev. Ahmet Savran), 133; İbnü'l-Cevzî, el-Muntazam, XVIII: 161; İbnü'l-Esîr, el-Kâmil, XI: 250; İbn Hallikân, Vefeyâtü'l-a'yân, V: 145.

53 İbn Cübeyr, Endülüsten Kutsal Topraklara, çev. İsmail Güler (İstanbul: Selenge Yayınları, 2017), 86.

54 İbn Hallikân, Vefeyâtü'l-a'yân, V: 146; Gök, Musul Atabeyliği, 127.

55 İbnü'l-Esîr' in kayıtlarından babasının Musul Atabegi İmâdeddin Zengî döneminde Vezir Cemâleddin'in Cizre'deki nâibi, Kutbeddin Mevdûd döneminde de Dîvânü'l-harâc reisi olduğu anlaşılmaktadır. Bkz. Abdülkerim Özaydın, “İbnü'l-Esîr, İzzeddin”, DİA, XXI, (İstanbul: TDV, 2000), 26. 
ve bir miktar para göndermişti. ${ }^{56}$

Öyle ki, yapmış olduğu hayır işleri ve cömertliği neticesinde şâirler ve edipler uzak şehirlerden onun yanına gelmeye, beyitlerini sunmaya başlamışlardı. Devrin büyük şâirlerinden Haysa Beysa (ö. 574/1179) veziri dizeleriyle öven şâirler arasındadır. ${ }^{57}$ Cemâleddin Muhammed el-İsfahânî bilhassa Cuma günleri âlimlerle bir araya gelip fikir telakkîsinde bulunurdu. Şâirlerin ona beyitlerini sunmaları gibi diğer ilim adamları da eserlerinde veziri anmayı ihmâl etmezlerdi. İmâdeddin el-İsfâhânî, 542 senesi Zilkade ayında (Mart-Nisan 1148) Musul'u ziyaret ettiğinde iki defa Cuma Namazı esnâsında Cemâleddin'le berâber camide bulunmuş; burada hem fakihlerle mütâlaa imkânı bulmuş, hem de vezir için yazmış olduğu kasîdesini sunmuştur. ${ }^{58}$ Ebû Abdullah Muhammed b. Nasr Sağîr el-Kayserânî (ö. 548/1153) de Vezir Cemâleddin için kasîde yazan şâirlerdendir. ${ }^{59}$ Bu âlimlerden Doğu Anadolu'da Ahlatşahların (494-604/11001208) da hizmetinde bulunmuş olan dönemin en önemli hekimlerinden Mühezzebüddîn b. Hübel, Ebü'l-Hasan Ali b. Ahmed el-Bağdâdî (ö. 610/1213) ${ }^{60}$ de vezir tarafindan hürmet görmüş ve bu iyilikleri unutmayarak et-tıb el-Cemâlî adlı eseriyle Cemâleddin'i onurlandırmıştır. ${ }^{61}$

Cemâleddin Muhammed el-İsfahânî, bilhassa Hicaz bölgesinde yapmış olduğu hayırseverlikleriyle nazar-1 dikkati celbetmektedir. Bunun yanı sıra pek çok şehirde de vezirin yardımseverliğinin izlerini görmek mümkündür. Bu hususta kaynakların verdiği mâlûmata da değinmek gerekmektedir. İbnü'l-Cevzî, (ö. 597/1201) Cemâleddin Muhammed el-İsfahânî’nin cömertlik vasıflarına dâir övgüler sıralamış, vezirin güzel ahlâklı, hayır sahibi, iyi huylu olduğunu mallarından her dâim ihtiyaç sâhiplerine bolca sadakalar verdiğini, bunların Bağdat halkına da ulaştığını belirtirken; fakihler, zâhitler ve mutasavvıfların da bu sadakalardan yararlandığını, kendisinden yardım isteyen hiç kimseyi hayal kırıklığına uğratmadığını, Harem'in kapılarını sağlamlaştırarak eşikler yaptırdığını, Arafat'a su kaynağı getirttiğini ve özellikle Mekke ve Medine'de yaptığı hayırların son derece önemli işler olduğunu zikretmiştir. ${ }^{62}$

Onun Mekke ve Medine'de yaptığg hayırları vezirler şöyle dursun büyük halifelerin dahi yapamadığını belirten İbn Cübeyr (ö. 614/1217), Haremeyn'de Müslümanların umûmi menfaati için plânlanan mekânların yapımına 15 yıldan fazla vakit harcadığını vurgulamıştır. Buna göre su kuyuları yaptırmış, yağmur suyunun toplanması için yol kenarlarına arklar kazdırmış, Haremeyn'deki binaların onarılmasına çok miktarda para harcamış, vezirin en faydalı hizmeti de Arafat'a su getirmesi olmuştur. Ayrıca Medine'nin surlarını yaptırması yanında bütün Harem kapılarını yeniletmiş, kutsal Kâbe'nin kapısını yeniletip yaldızlı gümüşle kaplatmış, Kâbe’nin eşiğini de saf altınla kaplatarak eski kapısından kendisine bir tabut yaptırtmıştır. Ölünce naâşının

56 İbnü'l-Esîr, Atâbekiyye, 130.

57 Bündârî, Zübdetü'n-Nusra, 193; İbn Hallikân, Vefeyâtü'l-a'yân, V: 144.

58 Bündârî, Zübdetü'n-Nusra, 193.

59 İbn Hallikân, Vefeyâtü'l-a'yân, V: 144.

60 Hayatı hakkında bkz. İbnü'l-İbrî, Abû'l-Farac Tarihi, II: 494-495; İbn Ebû Useybia, Uyûnü'l-enbâ fì tabakāti'letıbbâ, nşr. Nizâr Rıza (Beyrut: Dâru mektebetü'l-hayât, ts.), 407-409.

61 İbn Ebû Useybia, Uyûnü'l-enbâ, 409; Abbâs, "Vezîru Atabeki Mevsıl," 40.

62 İbnü'l-Cevzî, el-Muntazam, XVIII: 161. 
ona konulmasını ve cenâzesine hac yaptırılmasını da vasiyet etmiştir. ${ }^{63}$ İbnü'l-Esîr'de Mina yakınlarındaki Mescid-i Hayf'1 yenilettiğini ve bu uğurda büyük paralar harcadığını, ayrıca Kâbe'den ayrılmış olmakla beraber onun parçası olarak da kabul edilen Hicr' $i^{64}$ onardığını, bunları yaptırmak isteyince de Abbâsî Halifesi Muktefî-Liemrillâh'a (530-555/1136-1160) kıymetli hediyeler göndererek bu konuda iznini talep ettiğini zikretmiştir. ${ }^{65}$ Ayrıca Arafat'ta bulunan Mescid-i Nemire'yi ve insanların Arafat'a çıkarken kullandıkları basamakları tâmir ettiren yine Vezir Cemâleddin olmuştur. ${ }^{66}$

Yaptığg en faydalı işler arasında İbn Cübeyr'in de belirttiği gibi Medine şehrini surlarla çevrilmesi olduğunu vurgulayan İbnü'l-Esîr, daha önce kentin surlarla çevrili olmadığını ve bu sebeple Bedevîlerin yağmalamasına mâruz kaldığını, Medine halkının Bedevîlerden oldukça sıkıntı çektiklerini kaydetmiştir. ${ }^{67}$ Müellif bizzat kendisi Medine'deki insanların Cuma namazının ardından Cemâleddin'e duâ ettiklerini görünce bunun sebebini kendilerine sormuş ve ona: "Medine'de bulunan herkesin ona duâ etmesi lâzım. Çünkü biz çok sıkıntı ve zor hâlde idik, Bedevîlerden sıkıntı çekerdik. Bizde avret yerlerimizi örtecek, karnımızı doyuracak bir şey bırakmazlardı. Cemâleddin bu surlarl yaptırd, bunun sayesinde bize karşı kötülük düşünenlerden korunuyoruz. Ona nasıl duâ etmeyelim ki!” diyerek cevap vermişlerdi. Medine'deki hatip de hutbede şöyle duâ etmiştir: “Allahım! Sen Nebî'nin haremini surlarla koruyan Muhammed b. Ali b. Ebû Mansûr'un harimini koru. Onun sadece bu iyiliği bile övülmek için yeterlidir. Onun sadakaları doğuyu ve batıyı kuşatır. "68

Cemâleddin el-İsfahânî, her yıl Mekke ve Medine'deki güçsüzlere, fakirlere, ihtiyaç sâhiplerine bu iki şehrin halkından Mescid-i Nebevî ve Mescid-i Harâm'a kendilerini adayanlara bir yıl yetecek kadar para, yiyecek ve giyecek gönderirdi. Ayrıca Mekke ve Medine'ye gelip mücâvir olarak ikamet edenlere her sene ihtiyaç duydukları malzemelerin de tedarik edilmesini sağlar, zayıflardan ve yayalardan yolda kalanlar taşınırdı. Vezirin huzuruna sadece Musul ve civarından değil Bağdat ve İsfahân halkından dahi ileri gelenler, çocuklar, vezirler, kâtipler, makam sâhipleri ve eşraftan gruplar gelir o da câize verir, ihsanlarda bulunurdu. ${ }^{69}$ Her gün

63 İbn Cübeyr, Endülüsten Kutsal Topraklara, 86; Krş. İbnü’l-Ezrak, Târîhu Meyyâfârikîn ve Âmid: Kısmü'lArtukiyyîn, (nşr. ve çev. Ahmet Savran), 132; İbnü’l-Cevzî, el-Muntazam, XVIII: 161; İbnü’l-Esîr, Atâbekiyye, 128; İbn Hallikân, Vefeyâtü'l-a'yân, V: 144.

64 Semûd kavminin yaşadığı kabul edilen bölge ve burada yer alan şehir olan Hicr hakkında bkz. Fuat Günel, "Hicr", DIA, XVII, (İstanbul: TDV, 1998), 455-456.

65 İbnü'l-Esîr, el-Kâmil, XI: 250; a. mlf. Atâbekiyye, 128.

66 İbnü'l-Esîr, Atâbekiyye, 128; Dursun Ali Şeker, "Mescid-i Nemire”, DİA, XXIX, (Ankara: TDV, 2004), 290-291.

67 İbnü'l-Esîr, Atâbekiyye, 128. Siklıkla yağmalamalara uğrayan bölge ve hac yollarının sonraki dönemlerdeki durumu ve güvenliğini sağlama yönünde alınan tedbirler ile îmar faâliyetleri hakkında bkz. Tahir Sevinç, Osmanlı Devleti İdaresinde Surre-i Hümâyun, Surre Akçesi, Kaynaklart ve Haremeyn'e Ulaştırlmast-XVII. ve XVIII. Yüzyıllar, (İstanbul: İdeal Kültür Yayınc1lık, 2020), 206-214, 313-347.

68 İbnü'l-Esîr, Atâbekiyye, 128. Medine surları hakkında ayrıca bkz. Harry Munt, "The Construction of Medina's Earliest City Walls: Defence and Symbol", Proceedings of the Seminar for Arabian Studies 42, (2012), 233-244.

69 İbnü’l-Ezrak, Târîhu Meyyâfârikîn ve Âmid: Klsmü'l-Artukiyyîn, (nşr. ve çev. Ahmet Savran), 132; İbn Hallikân, Vefeyâtü'l-a'yân, V: 144. 
evinin kapısına çıkar, fakir fukaraya 100 dinar dağıtır, din âlimleri, sâlihler ve eşrafa tahsis ve taahhüt ettiği ödemeleri ise bu rakamın dışında tutardı. ${ }^{70}$

O, Irak’tan Dımaşk'a kadar bütün umûmi yolların bakımını yaptırmış, kuyular açtırmış, çöllerde menziller tespit ederek yolcuların sığınacağı barınaklar inşa ettirmiştir. Hanlar satın alarak kira veremeyen fukaranın, yolcuların konaklamasını sağlamış; bu hanları ve menzilleri çalıştıranlara aylık bağlamış ve bunların gelirini de vakfetmiştir. ${ }^{71}$ İbnü'l-Esîr, Vezir Cemâleddin'in hayır işlerine dâir kıymetli misaller vermiştir. Babası tarafından İbnü'l-Esîr'e naklen anlatılanlara göre; "Cemâleddin'e yemek getirildiğinde onun çoğu zaman bu yemekten ve tatlıdan birer parça alıp önündeki ekmeğin arasına koyduğunu görürdüm. Ben ve onu bu hâlde görenler onun bu ekmeği oğlu Ali'nin annesi olan cariyeye götürdüğ̈̈nü zannederdik. Bir defasında vezir, Atabeg Kutbeddin ile beraber Cizre'ye geldi. Ben de Cizre'nin dîvânını idâre ediyordum. Cariyesini hamama girmesi için bizim evimize gönderdi, ben de vezir ile çadırda bulunduğum sırada yemek yedi. Her zaman yaptı̆̆ şeyleri burada da yaptı. Sonra halk dă̆lld, ben de tam kalkmıştım ki, 'otur' diye seslendi ve içeride hiç kimse kalmayınca bana: 'Bu gün seni kendime tercih ettim; çünkü çadırda her zaman yaptığım şeyi yapmam mümkün değil. Bu ekmeği al ve bu mendilin içine koyup koltuğunun altında götür. Yolda bir fakir görür ve onun buna lâyık olduğuna inanırsan yanına otur ve bu yemeği ona yedir'dedi. Ben de vezirin dediklerini yaptım. Yanımda büyük bir kalabalık vardl, bunu yaparken beni görmesinler diye yolda onları dağıttım, gulâmlarımla kaldım Bir yerde çocukları ve hanımı yanında olan âmâ bir zat gördüm, çok fakir bir hâldeydiler. Merkebimden aşă̆ indim, yemeğ $i$ çıkarıp onlara yedirdim. Adamdan da ertesi sabah erkenden târif ettiğim adrese, yani kendi evime, gelmesini istedim. Fakat ona kim olduğumu söylemedim; 'Ben sana Cemâleddin'in sadakalarından bir miktar alırım' dedim. Sonra ikindi vakti Cemâleddin'in yanına gittiğimde 'Sana dediğim hususu ne yaptın?' diye sordu ve ben de onun devletiyle ilgili olarak yapılan şeyleri anlatmaya başladım. Cemâleddin bana: 'Ben sana onları sormuyorum; sana verdiğim yemeği ne yaptığını soruyorum' deyince, ben de durumu anlattım. Çok sevindi ve 'Keşke o adama âilesiyle birlikte sana gelmelerini söyleseydin, onlarl, giydirir, bir kaç dinar verirdin, her ay için de maaş tahsis ederdin' dedi. Ben de öyle yaptığımı belirtince vezirin sevinci bir kat daha arttı. ",72

İbn Hallikân (ö. 681/1282) da Musul'u son derece olumsuz etkileyen bir kıtlık sırasında Cemâleddin el-İsfahânî’nin öşür gelirlerini halkın sefâletini hafifletmek için harcadığını vurgulamıştır. ${ }^{73}$ Musul'da yaşanan bu kıtlıkta Cemâleddin el-İsfahânî neredeyse tüm şahsî malını halka dağıtmıştı. Rivâyete göre; Musul'da yiyecek kıtlığı olup ve fiyatlar yükselince sâlih kişilerden Ömer isimli bir zâta Cemâleddin bir miktar mal getirmiş ve bu emtiayı hak sâhiplerine dağıtmasını istemişti. Mal bittiğinde ise kendisine haber gönderilmesini

70 İbnü'l-Esîr, el-Kâmil, XI: 251; a. mlf., Atâbekiyye, 129.

71 İbn Cübeyr, Endülüsten Kutsal Topraklara, 87.

72 el-Kâmil, XI, 251-252.

73 Vefeyâtü'l-a'yân, V: 144. 
tembihlemişti. Bir süre sonra muhtaçlar fazla olduğundan dağıtılanlar tükenince durumu bildirmek üzere Cemâleddin'e bir elçi gönderildi. Cemâleddin, Şeyh Ömer'e yeniden mal gönderdi, onlar da tükendi. Sonra yeniden Cemâleddin'den dağıtılacak mallar istemek üzere bir adam gönderildi. Vezirin elinde o sırada gönderecek hiçbir şey bulunmuyordu. $\mathrm{O}$ da başındaki kavuğunu sırtındaki elbisesini çıkarıp onlara gönderdi ve elçiye dedi ki: "Şeyh’e söyleyin, benden istemekten vaz geçmesin.” Elbiseler Şeyh Ömer'e ulaştığında, ağlamış ve elbiseleri satarak parasını ihtiyaç sâhiplerine dağıtmıştır. ${ }^{74}$

Cemâleddin, Gürcülerden geri alınmış olan Kars şehrine de 9.000 dinar göndererek yıkılmış olan kent surunu yaptırmış, Gürcü Kralı'na bir elçi gönderip Tiflis şehrindeki Müslüman hastalar ve güçsüzler yararına bir hastane yaptırmak istediğini bildirmiştir. Gürcü Kralı ise Cemâleddin'e: "Ben kendi paramla yaptırırım” şeklinde cevap vermiştir. ${ }^{75}$

Hicaz dışındaki şehirlerde de îmar faâliyetlerine çok önem verdiği görülen İsfahânî Cizre ve Fenek ${ }^{76}$ arasındaki el-Yâryâr Köprüsü’ne çok büyük harcamalar yaparak dört gözünü en güzel şekilde inşâ ettirmiş, Musul önündeki Bâbü'l-Hasbe'de de bir köprü yaptırtmıştır. ${ }^{77}$ Cizre civarında Dicle Nehri üzerinde yontma taş, demir, kurşun ve kireç gibi malzemelerle halkın daha önce eş benzerini görmediği bir köprünün yapımına başlayan ve ona pek çok paralar harcayan vezir, köprünün sadece orta gözünün tamamlanmasının eksik kaldığı sırada tutuklanmıştır. ${ }^{78}$ İbnü'l-Esîr bu köprü yakınlarında el-Erbâd adıyla bilinen bir nehir üzerinde de bir köprü yaptırdı̆̆ını zikretmiştir. ${ }^{79}$

Cemâleddin el-İsfahânî, Nusaybin'de bîmâristan yaptırıp ona bir kısım vakıflar bağışlamıştır. Bîmâristanın hizmet verebilmesi için gerekli teçhîzat ve ilaçları sağladığı gibi hastaneye hekimler de tâyin etmiştir. Ayrıca her yıl burası için pek çok harcamalarda da bulunmuştur. ${ }^{80}$ Musul ve Nusaybin'de yetimler için mektepler açıp onların yiyecek, elbise, muallim ücretlerini bizzat kendisi karşılamıştır. ${ }^{81}$ Yine Musul, Sincâr, Nusaybin ve başka yerlerde ribâtlar yaptırmış, her yerden ve her kesimden yolcular buralarda konaklamışlardır.

\section{Sonuç}

İmâdeddin Zengî devrinde girdiği Musul Atabeglerinin hizmetine I. Seyfeddin Gazi ve

74 İbnü’l-Esîr, Atâbekiyye, 129; Abbâs, "Vezîru Atabeki Mevs1l," 35.

75 İbnü'l-Ezrak, Târîhu Meyyâfârikîn ve Âmid: Kısmü'l-Artukıyyîn, (nşr. ve çev. Ahmet Savran), 132.

76 Cizre yakınlarındaki bu kale hakkında bkz. Yâkūt, Mu'cemü'l-büldân, IV: 278.

77 İbnü'l-Ezrak, Târîhu Meyyâfârikîn ve Âmid: Kısmü'l-Artukıyyîn, (nşr. ve çev. Ahmet Savran), 132-133.

78 İbnü'l-Ezrak, Târîhu Meyyâfârikîn ve Âmid: Kısmü 'l-Artukıyyîn, (nşr. ve çev. Ahmet Savran), 133; İbnü'l-Esîr, el-Kâmil, XI: 251; a. mlf., Atâbekiyye, 129.

79 el-Kâmil, XI: 251; a. mlf., Atâbekiyye, s. 129.

80 İbnü'l-Ezrak, Târîhu Meyyâfârikîn ve Âmid: Klsmü'l-Artukıyyîn, (nşr. ve çev. Ahmet Savran), 133. Bîmâristan hakkında ayrıca bkz. Ahmet Acıduman-Murat Aksu, "Nașībīn/Nusaybin Bīmāristanı Tarihine Bir Katkı", Lokman Hekim Dergisi VIII/2 (2018), 120-132.

81 İbnü'l-Ezrak, Târîhu Meyyâfârikîn ve Âmid: Kısmü'l-Artukıyyîn, (nşr. ve çev. Ahmet Savran), 133; Gök, Musul Atabeyliği, 125. 
Kutbeddin Mevdûd'in dönemlerinde devam etmiş olan Cemâleddin Muhammed el-İsfahânî, uzun yıllar boyunca görev yaptığı Zengî hânedanı tarihinde oldukça mühim bir rol oynamıştır. Onun Yakındoğu'da böylesine güçlü olan Musul Atabegliği'nde birden fazla atabeg döneminde görev yapmış olması ve sadece siyasî değil pek çok alanda gerçekleştirdiği başarılı icrâatları, Büyük Selçuklu Devleti'de de uzun yıllar vezirlik yapmış ve ismi ölümsüz bir hüviyet kazanmış olan Nizâmülmülk'ün (ö. 485/1092) yaratmış olduğu etkilere dahi benzetilmiştir. ${ }^{82}$ Nitekim ilginç bir tesadüfle iki vezir de İslâm tarihine nice olumlu katkılarda bulunmuş, ülkelerinde düzeni bozabilecek tehlikelere karşı zamanında müdahâlelerde bulunmayı ihmâl etmemiş ve civar bölgelerdeki hâkimlerin yaşadıkları siyasî gelişmeleri her zaman dikkatle tâkip ederek dâima birleştirici ve bütünleştirici olmaya çalışmıştır. Bununla beraber hayırsever vasıflarıyla bilinmelerine rağmen bilhassa hayatlarının son dönemlerinde devlet ricâlinin kendilerini yoğun bir şekilde karalama teşebbüslerine de mâruz kalmışlardır.

Cemâleddin sâhip olduğu müspet özellikler sebebiyle ön plâna çıkarak kendisini göstermeyi başarmış ve İmâdeddin Zengî tarafından yeteneklerinin keşfedilmesini sağlamıştır. Her zaman Atabeg Zengî’ye ve onun hânesine bağlılık gösteren Cemâleddin, atabegin çocukları arasındaki meselelerde denge kurmaya çalışmış, siyasî krizlerde sunduğu çözümlerle de dikkat çekmiştir. Bütün bunları gerçekleştirirken kendi durumunu da kurnazlıkla güçlendirmeyi ihmâl etmediği görülmektedir. Nitekim Musul Atabegliği'nin devam etmesi Cemâleddin'in vezâretinin de idâmesini sağlayacağından hem Irak Selçuklu Meliki'ni derdest etmiş; hem de Nûreddin Mahmud Zengî'nin Musul'a hâkim olmasını engellemiştir. Özellikle Haremeyn ve civârında yapmış olduğu hayırlara çok miktarda para sarf edilmesi vezirin gözden düşmesine sebep olmuşsa da bu kadar yüklü harcamalara, elindeki maddî imkânlara rağmen Cemâleddin el-İsfahânî’nin son derece mazbut, zâhidâne bir yaşam sürdürdüğü de dikkat çekmektedir.

Bununla berâber Cemâleddin Muhammed el-İsfahânî, Musul Atabegliği'nin âlimler için cezbedici bir hâle dönüşmesinde etkili olduğu gibi, onlara sadece hediyeler ve ödüller vermekle kalmamış; âlimlerle sıkça zaman geçirerek ilmî sohbetlerde de bulunmuştur. Başta Musul olmak üzere pek çok şehirde ilmî faâliyetleri desteklemiş, mescidler, ribâtlar, yetimler için mektepler, hastaneler gibi çeşitli hayır kurumları inşâ ettirerek bu kentlere insanların gelmesine vesîle olmuştur. Mekke ve Medine'deki kutsal topraklara duyduğu özel ilgi, yakinen göstermiş olduğu alâka ve îmarı için gösterdiği gayretler Cemâleddin el-İsfahânî’nin kaynaklarda hayırlarıyla ve cömertliğiyle anılmasına vesile olmuştur.

\footnotetext{
Hakem Değerlendirmesi: Dış bağımsız.

Çıkar Çatışması: Yazar çıkar çatışması bildirmemiştir.

Finansal Destek: Yazar bu çalışma için finansal destek almadığını beyan etmiştir.
}

Peer-review: Externally peer-reviewed.

Conflict of Interest: The author has no conflict of interest to declare.

Grant Support: The author declared that this study has received no financial support.

82 Guédy, Iranian Elites, 244. 


\section{Kaynakça/References}

Abbâs, Ali Sultan. "Vezîru Atabeki Mevsıl Cemâleddin el-İsfahânî (521-559/1127-1163).", Moss 11. (2006): 33-48.

Acıduman, Ahmet-Aksu, Murat. "Nașībīn/Nusaybin Bīmāristanı Tarihine Bir Katkı.", Lokman Hekim Dergisi. VIII/2 (2018): 120-132.

Alptekin, Coşkun. The Reign of Zangi (521-541/1127-1146). Erzurum: Atatürk Üniversitesi Yayınları, 1978. Alptekin, Coşkun. Dimaşk Atabeglĭgi (Tog-Teginlilier). İstanbul: Marmara Üniversitesi Yayınları, 1985.

Brosset, M. F.. Gürcistan Tarihi (Eski çağlardan 1212 yılına kadar). Çeviren Hrant D. Andreasyan. Hazırlayan Erdoğan Merçil. Ankara: TTK, 2003.

Bündârî. Zübdetü'n-Nusra ve nuhbetü'l- 'usra. Çeviren Kıvameddin Burslan. Irak ve Horasan Selçukluları Tarihi. İstanbul: Maarif Matbaası, 1943.

Dihhudâ, M. Alî Ekber. Luġatnâme. Hazırlayanlar M. Muîn ve Seyyid Ca'fer Şehîdî. XI. Tahran: Tahran Üniversitesi, 1998.

Gök, Halil İbrahim. Musul Atabeyliği Zengiler (Musul Kolu 1146-1233). Ankara: TTK, 2013.

Gök, Halil İbrahim. "XII. Yüzyılda Musul'da Yaşamış Seçkin Bir Sima: "Vezir Cemâleddin Muhammed elİsfahân̂”, Bilim Yolu, Kırıkkale Üniversitesi Sosyal Bilimler Enstitüsü Dergisi. Say1: 3 (2003), s. 511-529.

Guédy, David D. Iranian Elites and Turkish Rulers A History of Isfahān in the Saljūq Period. London-New York: Routledge, 2010.

Gündüz, Ahmet. "Şehrizor.” DİA. XXXVIII: 473-475. İstanbul: TDV, 2010.

Günel, Fuat. "Hicr.” DIA. XVII: 455-456. İstanbul: TDV, 1998.

Honigmann, E.. “Rahbe.” İA. IX: 601-604. İstanbul: MEB, 1964.

Hüseynî. Ahbârü'd-Devleti ’s-Selçukıyye. Çeviren Necati Lugal. Ankara: TTK, 1943.

İbn Cübeyr. Endülüsten Kutsal Topraklara. Çeviren İsmail Güler. İstanbul: Selenge Yayınları, 2017.

İbn Ebû Useybia. Uyûnü 'l-enbâ fì tabakāti'l-etıbbâ. Neşreden Nizâr Rıza. Beyrut: Dâru mektebetü'l-hayât, ts. İbn Hallikân. Vefeyâtü'l-a'yân. Neşreden İhsan Abbas. V. Beyrut: Dâru Sâdır, 1397/1977.

İbn Vâs1l. Müferricü'l-kürûb fỉ ahbâri Benî Eyyûb. Neşreden Cemâleddin eş-Şeyyâl. I. Kahire: 1953-1960.

İbnü'l-Cevzî. el-Muntazam fì târîhi'l-mülûk ve'l-ümem. Neşredenler Muhammed Abdülkādir Ahmed Atâ ve Mustafa Abdülkādir Atâ. XVIII. Beyrut: Dârü'l-kütübi'l-ilmiyye, 1992.

İbnü'l-Esîr. el-Kâmil fi 't-târih. Çeviren Abdülkerim Özaydın. İslâm Tarihi İbnü'l Esîr, el-Kâmil fi 't-Târih Tercümesi. X. İstanbul: Bahar Yayınları, 1987.

İbnü'l-Esîr. et-Târîhu'l-bâhir fi'd-devleti'l-Atâbekiyye. Neşreden Abdülkādir Ahmed Tuleymât. Kahire: Câmi'atü 'Ayn Şems, 1963.

İbnü'l-Ezrak el-Fârikī. Târîhu Meyyâfârikîn ve Âmid: Kısmü'l-Artukıyyîn. Neşreden ve Çeviren Ahmet Savran, Meyyâfârikîn ve Âmid Târihi (Artuklular Kısmı). Erzurum: Atatürk Üniversitesi Fen-Edebiyat Fakültesi, 1992; a. mlf., Târîhu Meyyâfârikîn ve Âmid. İngilizce kısmî Çeviren C. Hillenbrand, A Muslim Principality in Crusader Times the Early Artuqid State. İstanbul: Nederlands Historisch-Archaeologisch Instittuut, 1990.

İbnü'l-İbrî. Abû 'l-Farac Tarihi. Çeviren Ömer Rıza Doğrul. II. Ankara: TTK, 1999.

İbnü'l-Kalânisî. Zeylü Târîhi Dımaşk. Neşreden H. F. Amedroz. Beyrut: Matbaatü'l-âbâi'l-Yesûiyyîn, 1908. Keleş, Nevzat. Şeddâdîler (951-1199) Ortaçağ’da Bir Kürt Hanedanı. İstanbul: Bilge Kültür Sanat, 2016. 
Kesik, Muharrem. Selçuklu Müesseseleri ve Medeniyeti. İstanbul: Bilge Kültür Sanat, 2021.

Kesrevî, Ahmed. Şehriyârân-l Gumnâm. Tahran: Müessese-i İntişâât-i Nigâh, 2535 şş.

Kök, Bahattin. "Mevdûd b. İmâdüddin Zengî.” DİA. XXIX: 430-431. Ankara: TDV, 2004.

Kök, Bahattin. "Nûreddin Zengî, Mahmud." DİA. XXXIII: 259-262. İstanbul: TDV, 2007.

Merçil, Erdoğan. Selçuklular Zamanında Dîvân Teşkilâtı (Merkez ve Eyalet Dîvânları). İstanbul: Bilge Kültür Sanat, 2015.

Munt, Harry. "The Construction of Medina's Earliest City Walls: Defence and Symbol.", Proceedings of the Seminar for Arabian Studies 42, (2012): 233-244.

Öğün Bezer, Gülay. “Şeddâdîler.” DİA. XXXVIII: 409-411. İstanbul: TDV, 2010.

Öğün Bezer, Gülay. “Zengî, İmâdüddin.” DİA. XLIV: 258-261. İstanbul: TDV, 2013.

Özaydın, Abdülkerim. “İbnü'l-Esîr, İzzeddin.” DİA. XXI: 26-27. İstanbul: TDV, 2000.

Öztürk, Murat. Irak Selçuklu Devleti Atabegleri. İstanbul: Bilge Kültür Sanat, 2019.

Sevinç, Tahir. Osmanlı Devleti İdaresinde Surre-i Hümâyun, Surre Akçesi, Kaynakları ve Haremeyn'e Ulaştırılması-XVII. ve XVIII. Yüzyıllar. İstanbul: İdeal Kültür Yayıncılık, 2020.

Strange, G. Le. Doğu Hilafetinin Memleketleri. Çevirenler Adnan Eskikurt ve Cengiz Tomar. İstanbul: Yeditepe Yayınevi, 2015.

Süryânî Mihail. Süryani Patrik Mihail'in Vakainamesi (1042-1195). II. Çeviren Hrant. D. Andreasyan. Ankara: TTK'da bulunan yayımlanmamış nüsha, 1944.

Şeker, Dursun Ali. “Mescid-i Nemire.” DİA. XXIX: 290-291. Ankara: TDV, 2004.

Tomar, Cengiz. "İsfahânî, Cemâleddin.” DİA. XXII: 506-507. İstanbul: TDV, 2000.

Turan, Osman. Doğu Anadolu Türk Devletleri Tarihi. İstanbul: Ötüken Neşriyat, 2013.

Urfalı Mateos. Urfalı Mateos Vekayi-Nâmesi (952-1136) ve Papaz Grigor'un Zeyli (1136-1162). Çeviren Hrant D. Andreasyan. Ankara: TTK, 2000.

Yâkūt el-Hamevî. Mu 'cemü'l-büldân. Beyrut: Dâru Sâdır, 1977/1397, III-V.

Yürekli, Tülay. “Atabeg İmâdeddîn Zengî’nin Şahsî Hayatı.”, Nüsha 28 (2009/I): 114-122. 